\title{
Nhìn lại nền kinh tế Việt Nam 2008 phải trong bối cảnh khủng hoảng tài chính thế giới
}

\author{
Vương Quân Hoàng
}

January 22, 2009

Tạp Chí Cộng Sản

No. 795 (1-2009)

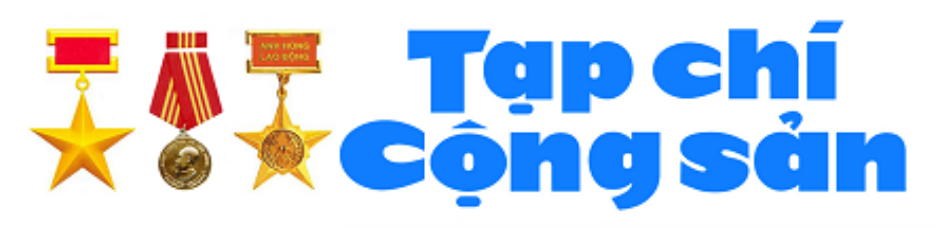

https://tapchicongsan.org.vn/nghien-cu/-/2018/1961/nhin-lai-nen-kinh-te-viet-nam-2008-phaitrong-boi-canh-khung-hoang-tai-chinh-the-gioi.aspx

\section{Tóm tắt:}

Kinh tế thế giới năm 2008 đã tác động rõ nét tới nền kinh tế nước ta. Chúng ta đã phải đối mặt với những khó khăn về vấn đề thanh khoản của hệ thống tín dụng, lãi suất ngân hàng cao, những cơn sốt giá lương thực và năng lượng, thị trường chứng khoán tiếp tục bị sụt giảm... Dưới sự lãnh đạo thống nhất của Đảng và Chính phủ, hệ thống kinh tế Việt Nam đã ghi nhận nhiều tín hiệu tích cực từ thị trường. Đến nay có thể nhìn lại những khó khăn đã vượt qua, đánh giá mức độ tác động của các yếu tố bên ngoài và xác định những thách thức sẽ phải đương đầu trong năm 2009. 


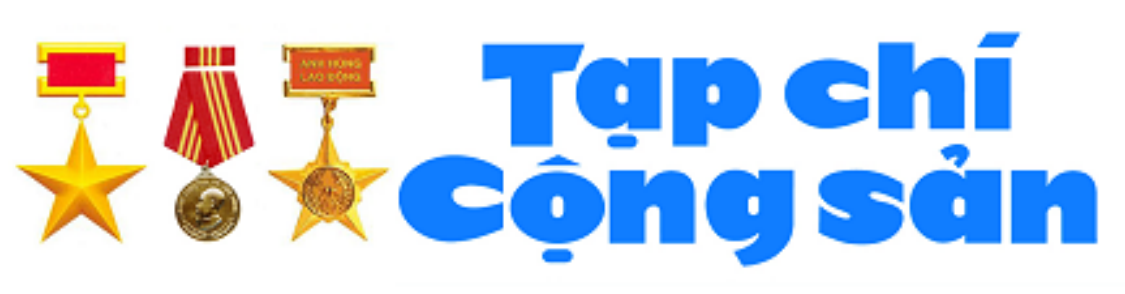

CƠ QUAN LÝ LUẬN CHÍNH TR! CỦA BAN CHẤP HÀNH

TRUNG ƯƠNG ĐẢNG CộNG SẢN VIẸTT NAM

๒าราวาอ 中文 ENGLISH ESPAÑOL

\title{
NGHIÊN CỨU - TRAO ĐỔ
}

\section{Nhìn lại nền kinh tế Việt Nam 2008 phải trong bối cảnh khủng hoảng tài chính thế giới}

\author{
VƯƠNG QUÂN HOÀNG
}

10:29, ngày 22-01-2009

\begin{abstract}
Kinh tế thế giới năm 2008 đã tác động rõ nét tới nền kinh tế nước ta. Chúng ta đã phải đối mặt với những khó khăn về vấn đề thanh khoản của hệ thống tín dụng, lãi suất ngân hàng cao, những cơn sốt giá lương thực và năng lượng, thị trường chứng khoán tiếp tục bị sụt giảm... Dưới sự lãnh đạo thống nhất của Đảng và Chính phủ, hệ thống kinh tế Việt Nam đã ghi nhận nhiều tín hiệu tích cực từ thị trường. Đến nay có thể nhìn lại những khó khăn đã vượt qua, đánh giá mức độ tác động của các yếu tố bên ngoài và xác định những thách thức sẽ phải đương đầu trong năm 2009...
\end{abstract}

\section{I - Nền kinh tế Việt Nam năm 2008}

Trong hình ảnh "Cơn sóng thần thế kỷ” được ông Ây-lan Grin-spen (Alan Greenspan), cựu Chủ tịch Cục dự trữ liên bang Mỹ sử dụng để nói về cuộc khủng hoảng tài chính năm 2008, có thể thấy được sức mạnh "siêu nhiên" không gì cản nổi của cơn bão tài chính này. Nhân loại có thể quan sát nó, đưa ra những cảnh báo về nó, gắng sức chống đỡ nó, nhưng kết cục nền kinh tế của hàng loạt các quốc gia trên thế giới đã bị tàn phá mạnh mẽ, khốc liệt. Các định chế tài chính, dù khổng lồ tới đâu, vẫn bỗng chốc trở nên nhỏ nhoi trước những khoản thua lỗ tín dụng đổ ụp xuống, như những cột nước cao hàng trăm mét ập vào bờ.

Kinh tế Việt Nam kết thúc năm 2007 với mức thu hút vốn đầu tư trực tiếp nước ngoài (FDI) đạt kỷ lục 17,8 tỉ USD và tăng trưởng kinh tế đạt $8,4 \%$. Thị trường chứng khoán có cả một năm thăng hoa với chỉ số Vn-Index thường xuyên ở trên ngưỡng 1.000 điểm kể từ nửa cuối tháng 1-2007 cho đến giữa tháng 11-2007, xen giữa là giai đoạn giảm nhẹ trong tháng 8 và 9-2007. Đến cuối 2007, Vn-Index vẫn đạt trên 900 điểm. Tâm lý chung là lạc quan và phấn khởi. Bởi 
vậy, mức nhập siêu tăng gấp gần 2,5 lần so với năm 2006(1) và chỉ số lạm phát lần đầu trở lại với 2 con số sau hơn một thập kỷ kể từ 1995(2) đã không thực sự khiến nhiều nhà kinh tế và giới kinh doanh lo âu.

Vào thời điểm đó, biến cố đã xảy ra trên thị trường tín dụng bất động sản của Mỹ. Theo một dây chuyền trong sự liên thông giữa thị trường bất động sản - tiền tệ - chứng khoán, biến cố này đẩy nhiều ngân hàng và định chế tài chính Mỹ nói riêng và thế giới nói chung tới tình trạng thua lỗ nặng, mất tính thanh khoản, đối diện với nguy cơ phá sản cao hoặc bị thâu tóm bởi các tổ chức khác, kể từ tháng 8-2007.

Chúng ta sẽ phải đối mặt với nhiều khó khăn hơn nữa khi bước vào năm 2009. Nhưng trước hết, hãy cùng nhìn nhận về những khó khăn đã phải trải qua trong năm 2008 để nhận diện những vấn đề cần quan tâm và tập trung nguồn lực giải quyết trong năm tới.

\section{1 - Tín dụng và vấn đề thanh khoản của hệ thống ngân hàng}

Trước những dấu hiệu gia tăng lạm phát xuất hiện từ cuối năm 2007, ngay từ đầu năm 2008, Ngân hàng Nhà nước (NHNN) đã theo đuổi chính sách tiền tệ thắt chặt. Những động thái đầu tiên được thực thi trong quí I-2008 gồm: (I) quy định tỷ lệ dư nợ cho vay, chiết khấu giấy tờ có giá để đầu tư và kinh doanh chứng khoán không vượt quá $20 \%$ vốn điều lệ của tổ chức tín dụng;(4) (II) tăng lãi suất cơ bản lên mức 8,75\%/năm (+ 0,5\%); và (III), phát hành 20.300 tỉ đồng tín phiếu bắt buộc. Những liệu pháp này đã gây “cú sốc” với nền kinh tế.

Chưa kể tới sự sụt giảm của thị trường chứng khoán, phản ứng của thị trường tín dụng Việt Nam khá tiêu cực. Trước tiên là khan hiếm nguồn tín dụng. Dù NHNN có "bơm" trở lại lưu thông 33.000 tỉ đồng ngay trong tháng 3-2008, nhưng trong quá trình tái cơ cấu các khoản tín dụng và đáp ứng yêu cầu tham gia mua tín phiếu bắt buộc, các ngân hàng thương mại (NHTM) khước từ phần lớn các yêu cầu tín dụng của doanh nghiệp. Thêm vào đó, lạm phát gia tăng cũng đẩy mặt bằng lãi suất lên cao theo nguyên lý "lãi suất dương". Liên tiếp trong tháng 5 và $6-2008$, lãi suất cơ bản được nâng lên $12 \%$, rồi $14 \%$. Với biên độ dao động cho phép là 150\%. Có thời điểm, lãi suất huy động vượt trên $20 \% /$ năm. Với đầu vào như vậy, doanh nghiệp có nhu cầu sử dụng vốn phải chấp nhận mức lãi suất rất cao để tồn tại. Không ít đơn vị sản xuất kinh doanh chấp nhận dùng "thuốc độc tín dụng" để tồn tại.

Giai đoạn từ tháng 4 đến tháng 7-2008 cũng chứng kiến sự biến động mạnh mẽ trong tương quan giữa đồng Việt Nam và đô la Mỹ (USD). Tỷ giá trên thị trường tự do và tỷ giá bình quân ngân hàng có mức chênh lệch rất lớn. Khoảng cuối tháng 3 đầu tháng 4-2008, nhu cầu sử dụng USD rất thấp. Tỷ giá tự do thấp hơn tỷ giá niêm yết chính thức. Sang tháng 5, đặc biệt vào nửa cuối tháng 6-2008, giá USD trên thị trường tự do có những lúc tăng cao đột biến. Khoảng cách giữa hai hình thức tỷ giá dao động từ 3.000 đồng đến 3.500 đồng/USD. 
Mặc dù, tới cuối tháng 10-2008 mức lãi suất trần mới dần được hạ xuống, nhưng với các can thiệp cương quyết bình ổn thị trường của Chính phủ và áp lực thanh khoản giảm đáng kể của hệ thống NHTM, mặt bằng lãi suất đã bắt đầu giảm từ nửa cuối tháng 7-2008. Trong quý IV-2008, chính sách tiền tệ được NHNN nới lỏng. Lãi suất cơ bản được điều chỉnh giảm đều đặn mỗi tháng 1\%. Từ ngày 5-12-2008, lãi suất cơ bản ở mức 10\%/năm.

Bước sang những ngày cuối năm 2008, cuộc đua trên chính trường Hoa Kỳ đã kết thúc với phần thắng thuộc về đại diện của Đảng Dân chủ nhưng hệ thống tài chính - tín dụng quốc tế vẫn chưa tìm lại được sự ổn định. Ông Ba-rắc Ô-ba-ma (Barack Obama), người được giới tài phiệt phố Wall ủng hộ, đang tích cực xây dựng bộ khung điều hành mới. "Thay đổi” (Change) là điều được người ta kỳ vọng nhiều nhất trong các chính sách bình ổn và khôi phục kinh tế sắp được thi hành. Tuy vậy, những chuyển biến tích cực khó mà xảy ra tức thì trong đầu năm 2009 , bởi cần có thời gian để ông chủ mới tiếp quản Nhà Trắng và các điều chỉnh chính sách phát huy tác dụng.

Do đó, và cùng với nhiều nguyên nhân khác nữa, bài toán nguồn vốn tín dụng còn tiếp tục gây đau đầu không chỉ với nhà quản trị kinh doanh, mà còn cả với các ngân hàng nước ta. Câu chuyện này nhiều khả năng kéo dài trong suốt cả năm 2009. Tăng trưởng tín dụng sau khi tăng cao tới 54\% trong năm 2007 đã giảm xuống còn 24\% trong năm 2008. Tuy lãi suất đi xuống từ tháng 7-2008, nhưng tăng trưởng tín dụng giảm mạnh trong nửa cuối năm. Nếu trong nửa đầu năm 2008, tăng trưởng tín dụng hằng tháng luôn dao động từ $2 \%$ - $5 \%$ thì tốc độ tăng của tháng 7 chỉ còn $0,7 \%$ và tiếp tục giảm xuống 0,56\% trong tháng 8-2008.

\section{2 - Đầu cơ và biến động giá cả}

Bối cảnh kinh tế thế giới nhiều biến động đã tạo môi trường thuận lợi cho các hoạt động đầu cơ quốc tế. Các nhà ngân hàng và tập đoàn đa quốc gia với tài sản hàng nghìn tỉ USD đang thao túng thị trường giao dịch hàng hóa thiết yếu và đầu vào sản xuất quan trọng. Lần lượt dầu thô, lương thực, và vàng trở thành đối tượng tập trung đầu cơ cao. Tiền tệ và tài sản tài chính của các quốc gia sẽ trở thành mục tiêu kế tiếp, theo một kịch bản xấu. Tình trạng này đã dẫn đến những hệ lụy sau:

Diễn biến phức tạp của giá dầu mỏ: Mâu thuẫn địa - chính trị ở một số khu vực dầu mỏ nhạy cảm trên thế giới và hoạt động tích cực của các nhà đầu cơ đã đẩy giá dầu thô tăng mạnh trong suốt 6 tháng đầu năm 2008, lên mức đỉnh cao, lần đầu tiên trong lịch sử kinh tế thế giới, dầu thô được giao dịch với giá 147 USD/thùng vào ngày 11-7-2008. Giá nhiên liệu tăng cao đặt các nền kinh tế toàn cầu trong tình trạng báo động đỏ về khủng hoảng năng lượng.

Xăng dầu là vật tư thiết yếu của sản xuất và hàng hóa quan trọng trong đời sống. Chính phủ Việt Nam từ lâu vẫn duy trì sự điều tiết chặt chẽ thông qua thuế và quy định giá. Đến ngày 21-7-2008, trước áp lực giá tăng kỷ lục của thị trường thế giới, giá bán lẻ xăng A92 tại Việt Nam có sự điều chỉnh lớn, tăng tới trên $30 \%$, từ 14.500 đồng/lít lên mức 19.000 đồng/lít. Thời kỳ tiêu dùng xăng giá cao dần qua đi kể từ nửa sau tháng 8-2008. Giá xăng bán lẻ được điều chỉnh giảm từ từ qua nhiều lần. Từ ngày 21-8 đến 8-12-2008 có 10 lần điều chỉnh giảm giá xăng trên thị trường, và dừng ở mức 11.000 đồng/lít (xăng A92). Thời điểm này, giá dầu thô thế giới dao động quanh mức 40 USD/thùng. 
Quan hệ cùng chiều giữa giá dầu mỏ thế giới và giá xăng bán lẻ tại Việt Nam là rõ ràng. Điểm đáng chú ý là trong thời kỳ tăng giá, tốc độ biến thiên giữa giá nội địa và quốc tế tương đối đồng đều. Nhưng bước sang giai đoạn điều chỉnh giảm, khoảng cách này nới rộng nhanh chóng. Đây là nguyên nhân dẫn tới nhiều bức xúc của người tiêu dùng với các đơn vị cung cấp xăng dầu bán lẻ vì cho rằng, giá thế giới giảm lớn hơn nhiều so với mức điều chỉnh trong nước.

Giá vàng lên xuống thất thường: Ở Việt Nam, vàng là hàng hóa đặc biệt, vừa là hình thức tiết kiệm được ưa thích, vừa là phương tiện thanh toán phổ biến. Năm 2008, mức độ tăng giảm của giá vàng tương đối lớn. Trong tháng 2 và 3-2008, chỉ số giá vàng liên tiếp tăng 11 và 13 điểm phần trăm. Hai tháng tiếp theo, chỉ số giá vàng giảm tổng cộng 13 điểm phần trăm. Tháng 7-2008, chỉ số giá vàng tăng cao nhất trong 10 tháng đầu năm, ở mức 220,46 điểm phần trăm. Nhưng đến hết tháng 9-2008, chỉ số giá vàng lại tụt xuống 200 điểm.

Các sàn giao dịch vàng ra đời bổ sung thêm một kênh đầu tư mới. Theo ghi nhận chung từ các kênh truyền thông, đây là loại hình đầu tư ẩn chứa nhiều rủi ro bởi chỉ trong một khoảng thời gian ngắn, thua lỗ có thể đạt tới quy mô rất lớn. Điều thú vị là, trong lúc nhiều hàng hóa chịu sự kiểm soát chặt chẽ về giá cả như chứng khoán (qua giới hạn biên độ dao động giá cổ phiểu), tiền tệ (qua cơ chế lãi suất cơ bản và biên độ dao động), xăng dầu (qua quy định giá bán lẻ)... thì giá vàng trên thị trường gần như được thả nổi.

"Sốt"giá lương thực: Nạn đầu cơ cũng khiến giá lương thực tăng nhanh từ tháng 4 đến tháng 6-2008. Trong ba tháng, giá gạo xuất khẩu của Việt Nam lần lượt tăng $23,6 \%, 40,4 \%$ và $26,7 \%$. So với tháng 1 , giá gạo xuất khẩu của tháng 4-2008 đã tăng gấp hơn hai lần. Giá gạo xuất khẩu của tháng 6-2008 tăng cao nhất, có lúc lên đến 1.005 USD/tấn.

Trước tình hình giá lương thực tăng cao, nhiều nước xuất khẩu gạo chủ chốt (trong đó có Việt Nam) đã lựa chọn giải pháp tạm ngừng xuất khẩu để quan sát. Trong khi đó, các quốc gia nhập khẩu nỗ lực tích lũy lương thực để duy trì ổn định giá cả và bảo đảm an ninh lương thực. Thực tế này dẫn tới hai hiệu ứng đồng thời: (I) giá lương thực tiếp tục bị đẩy lên cao; và (II) hành động "bơm" thêm tiền để mua lương thực của các chính phủ khiến tình hình lạm phát ở nhiều quốc gia càng thêm trầm trọng.

\section{Bảng 1: Tình hình xuất khẩu gạo qua 7 tháng đầu năm 2008}

\begin{tabular}{|c|c|c|c|}
\hline Tháng & Quy mô & $\begin{array}{c}\text { Xuất khẩu gạo Việt } \\
\text { Nam }\end{array}$ & $\begin{array}{c}\text { Giá bình quân thế } \\
\text { giới }\end{array}$ \\
\cline { 2 - 4 } & (1.000 tấn) & (USD/tấn) & (USD/tấn) \\
\hline 1 & 131 & 389 & 376 \\
\hline 2 & 328 & 424 & 465 \\
\hline
\end{tabular}




\begin{tabular}{|c|c|c|c|}
3 & 558 & 457 & 594 \\
\hline 4 & 657 & 565 & 907 \\
\hline 5 & 560 & 793 & 941 \\
\hline 6 & 210 & 1.005 & 805 \\
\hline 7 & 350 & 971 & 706 \\
\hline
\end{tabular}

Nguồn: Bộ Nông nghiệp và Phát triển nông thôn

Hiện tượng đầu cơ, tạo khan hiếm giả tạo mặt hàng gạo đã xuất hiện trên thị trường Việt Nam vào cuối tháng 4-2008. Chính phủ đã có những chỉ đạo kiên quyết hướng tới bình ổn giá cả và trấn an tâm lý. Sang tháng 6-2008, xuất khẩu gạo đã được phục hồi. Trong hai tháng 6 và 7-2008, giá gạo xuất khẩu của Việt Nam còn cao hơn mức giá bình quân thế giới.

\section{3 - Lạm phát và tăng trưởng}

Năm 2008 chứng kiến "căn bệnh" lạm phát hoành hành ở nhiều quốc gia. Trường hợp Dim-ba-bu-ê là điển hình của lạm phát cao. Lạm phát của nước này vào tháng 11-2007 là 24.470\%, tới tháng 10-2008 tăng lên tới $219.800 .000 \%$.

Để ứng phó với lạm phát, nhiều tổ chức quốc tế khuyến nghị các chính phủ thực thi triệt để chính sách cắt giảm chi tiêu công, cải thiện hiệu suất đầu tư, thắt chặt tiền tệ và tín dụng bằng biện pháp nâng cao lãi suất và dự trữ bắt buộc... Đây là những liệu pháp phù hợp với lý thuyết kinh tế, nhưng việc áp dụng luôn tạo ra các hiệu ứng phụ tiêu cực, nên cần có sự cân nhắc thấu đáo về thời điểm vận dụng và mức độ phù hợp.

Vận hành kinh tế không chỉ cần chú ý đến các biến số kinh tế vĩ mô như đầu tư, tiết kiệm, xuất và nhập khẩu..., mà còn phải hòa hợp tác động của các yếu tố hành vi nhân dân như tinh thần đoàn kết dân tộc, truyền thống đùm bọc và chia sẻ khó khăn, quyết định lựa chọn đáp ứng nhu cầu theo học thuyết Ma-xlâu (Maslow), lợi ích đầu tư, thương mại cộng đồng... Mục tiêu cuối cùng của mọi nhà nước là ổn định đời sống kinh tế, xã hội, chính trị. Lạm phát là một cản trở lớn trên con đường đi tới mục tiêu này. Và vì thế, chấp nhận bất ổn và đời sống dân cư khó khăn để đánh đổi lấy lạm phát thấp, trên thực tế, thường đẩy các quyết sách điều hành vĩ mô đi xa khỏi mục tiêu.

Lạm phát tại Việt Nam tăng mạnh trong nửa đầu năm 2008. Cuối tháng 6-2008, chỉ số giá so với kỳ gốc 2005 là 144,30\%. Trong quý III-2008, tốc độ tăng CPI giảm dần. Tính cả quý, CPI chỉ tăng 4,18 điểm phần trăm. Từ tháng 10-2008, xuất hiện dấu hiệu giảm phát khi CPI giảm xuống 148,2\% so với mức 148,48\% của tháng trước.

Dấu hiệu kinh tế đình đốn và tỷ lệ thất nghiệp gia tăng ngay tại các nền kinh tế phát triển khiến nhiều chính phủ lo ngại. 
Trong dài hạn, nền kinh tế Mỹ chưa xuất hiện dấu hiệu tăng trưởng tích cực. Nền kinh tế đầu tầu thế giới này đã ghi nhận tỷ lệ thất nghiệp $6,1 \%$ vào tháng 8-2008, mức cao nhất trong 5 năm trở lại đây. Nhiều khả năng, vấn đề thất nghiệp tại Mỹ sẽ còn trầm trọng hơn nữa. Từ tháng 11-2008, lãnh đạo các nền kinh tế thuộc khu vực châu Âu đã nhiều lần nhóm họp, tìm tiếng nói chung cho các giải pháp kích thích kinh tế.

Với Việt Nam, những tháng biến động vừa qua là một thời kỳ phân hóa mạnh giữa các doanh nghiệp dựa trên tiêu chí cơ bản nhất: năng lực cạnh tranh. Tình hình sản xuất trì trệ, khó khăn trong thanh toán và tín dụng bộc lộ những điểm yếu cần khắc phục: (I) năng lực quản lý hạn chế, (II) thiếu chiến lược và tầm nhìn kinh doanh, (III) đầu tư kém hiệu quả và thiếu cẩn trọng, (IV) hàm lượng giá trị gia tăng nhỏ bé. Nguyên nhân quan trọng, góp phần làm trầm trọng thêm các điểm yếu này là sự "hào hứng" quá mức với thị trường chứng khoán kéo dài từ năm 2006 đến hết năm 2007. Nguồn vốn được huy động dễ dàng đã tạo tâm lý chủ quan và hưởng thụ trong một bộ phận không nhỏ của cộng đồng doanh nghiệp.

Vụ Tín dụng thuộc Ngân hàng Nhà nước cho biết, tỷ lệ nợ xấu (cho các doanh nghiệp nhỏ và vừa vay) của hệ thống ngân hàng tính đến 31-7-2008 là 3,64\% (số tuyệt đối là 10.886 tỉ đồng), tăng $1 \%$ so với 2007 . Nếu đánh giá trên năng lực trả nợ đúng hạn, phần đông doanh nghiệp hoạt động ở mức trung bình, tỷ lệ gặp khó khăn gần $4 \%$, trong đó khoảng $1,5 \%$ có nguy cơ mất vốn.

Tại phiên họp thường kỳ của Chính phủ diễn ra trong hai ngày đầu tháng 12-2008, Thủ tướng Chính phủ đã đồng ý dành khoản tài chính 1 tỉ USD để thực hiện các giải pháp trọng tâm nhằm kích cầu đầu tư và tiêu dùng. Chính phủ cũng nhấn mạnh cần tập trung giải ngân và giải ngân hết các dự án có nguồn vốn đầu tư từ ngân sách, trái phiếu chính phủ và vốn ODA. Gói kích cầu không chỉ dừng ở đó, ngày 14-12-2008, Phó Thủ tướng Nguyễn Sinh Hùng khẳng định, gói kích cầu có thể lên đến 6 tỉ USD.

Trong thời kỳ đầu của quá trình công nghiệp hóa, hiện đại hóa, nhập siêu là hiện tượng khách quan khi năng lực chế tạo "máy cái" trong nước chưa đáp ứng đủ quy mô tăng trưởng của nền kinh tế. Chiếm tỷ trọng lớn trong hàng hóa nhập khẩu vào Việt Nam là nguyên liệu đầu vào sản xuất. Trong những tháng đầu năm 2008, giá thế giới của các nhóm hàng máy móc, thiết bị, dụng cụ, phụ tùng, xăng dầu, sắt thép... đều tăng mạnh. Do vậy, giá trị nhập siêu tăng nhanh. Tuy nhiên, kể từ tháng 5-2008, đà tăng thâm hụt thương mại quốc tế đã giảm nhờ các nỗ lực cắt giảm chi tiêu và tăng cường tiết kiệm. Giá trị nhập siêu từ tháng 1-2008 đến tháng 11-2008 là 16,9 tỉ USD. Điều đáng chú ý là, sau 5 tháng đầu năm, nhập siêu đã lên đến trên 14 tỉ USD.

\section{4 - Dòng vốn quốc tế}

Khi thị trường chứng khoán chưa ra đời, dòng vốn nước ngoài vào Việt Nam chủ yếu bằng hình thức FDI đã chứng tỏ là động lực quan trọng thúc đẩy tăng trưởng kinh tế. Trong giai đoạn 1992 - 1997, FDI đóng góp từ 5\% đến 10\% GDP hằng năm. 
Điều đáng mừng là, mặc dù kinh tế thế giới gặp rất nhiều khó khăn trong năm 2008, nhưng lượng vốn FDI cam kết dành cho Việt Nam vẫn tăng cao kỷ lục. Theo Tổng cục Thống kê, trong 11 tháng đầu của năm 2008, 1.059 dụ̣ án FDI được đăng ký mới với quy mô vốn cam kết vượt trên 60 tỉ USD. Đây là con số rất ấn tượng, gấp hơn 3 lần năm 2007 và hơn 8 lần so với năm 2005. Giải ngân vốn FDI năm 2008 cũng lập một kỷ lục với 10,1 tỉ USD cho đến hết tháng 11-2008, tăng 44,2\% so với cùng kỳ năm 2007. Mặc dù vậy, tỷ lệ vốn giải ngân mới chỉ bằng 17\% vốn đăng ký.

Nguyên nhân giải ngân chậm, theo khảo sát của Viện Nghiên cứu quản lý kinh tế trung ương tại 140 doanh nghiệp có vốn FDI, tập trung vào bốn nhóm lý do: (I) thay đổi chính sách ở địa phương (20\%), (II) khó khăn về giải quyết thủ tục đầu tư (17\%); (III) thay đổi trong chiến lược kinh doanh của công ty mẹ, bắt nguồn từ những biến cố kinh tế toàn cầu (15\%); và (IV) môi trường đầu tư không thuận lợi như dự đoán ban đầu (17\%).

Bên cạnh dòng $\mathrm{FDI}$, vốn đầu tư gián tiếp (FPI) xuất hiện tại Việt Nam khá sớm. Tám quỹ đầu tư, quản lý lượng vốn khoảng 700 triệu USD đã hiện diện từ đầu thập niên 90 của thế kỷ XX. Khó khăn trong tìm kiếm cơ hội bỏ vốn và tác động của khủng hoảng tài chính 1997 đã chuyển hướng dòng vốn này ra khỏi Việt Nam.

Sự sôi động của thị trường chứng khoán đã thu hút rất nhiều quan tâm của giới đầu tư tài chính quốc tế. Theo thống kê của Emerging Porfolio Fund Research Global (EPFR), hiện có ít nhất 25 quỹ đầu tư dành cho Việt Nam với quy mô vốn trên 10 tỉ USD. Dù rằng "mây đen" khủng hoảng tài chính toàn cầu đang lởn vởn trên "bầu trời" nền kinh tế Việt Nam, giữa các quỹ đầu tư vẫn có một đồng thuận rằng, rất đông các nhà đầu tư toàn cầu đang bỏ vốn vào sự trỗi dậy trở lại của một nền kinh tế ổn định và tăng trưởng cao như Việt Nam.

Năm 2008, lần đầu tiên GDP bình quân đầu người của Việt Nam vượt qua mốc 1.000 USD. Mục tiêu tăng trưởng kinh tế cho năm 2009 được Quốc hội đặt ra là 6,5\%. Trong các kịch bản thiếu lạc quan hơn, các đại diện Ngân hàng Phát triển châu Á $(\mathrm{ADB})$ và Quỹ Tiền tệ quốc tế (IMF) đều đồng ý rằng, mức tăng trưởng $5 \%$ hoàn toàn khả thi với Việt Nam. Đại diện Ngân hàng Thế giới (WB) tin tưởng tăng trưởng kinh tế Việt Nam sẽ vượt qua con số 6,5\%.

\section{5 - Sụt giảm trên thị trường chứng khoán}

Sự vận động lên xuống của các chỉ số chứng khoán cũng như giá các loại cổ phiếu có tác động ngày càng lớn hơn tới đời sống xã hội. Đến cuối năm 2008, giá trị các chỉ số chứng khoán giảm tới $70 \%$ so với đầu năm. Ngay một số cổ phiếu thuộc nhóm "blue-chip" còn có mức sụt giảm lớn hơn nhiều, như SSI (- 84\%) và FPT (- 78\%).

Nửa đầu năm 2008, chỉ số chứng khoán tụt dốc nhanh chóng. Đầu tháng 1-2008, Vn-Index còn trên 900 điểm, tới đầu tháng 6-2008, hàn thử biểu kinh tế lần đầu rơi xuống dưới ngưỡng 400 điểm. Thị trường tiếp tục giằng co trong quý

III-2008. Từ sau tháng 10-2008, thị trường chứng khoán liên tục giảm điểm. Tới ngày 11-12-2008, Vn-Index chỉ còn 288 điểm. Tại Hà Nội, HaSTC-Index còn 101 điểm. Trước đó, thị trường Hà Nội thậm chí còn lùi về sau vạch xuất phát, tụt xuống 97,61 điểm khi kết thúc phiên giao dịch ngày 27-11-2008. 
Sau khi Việt Nam gia nhập WTO, thị trường bán lẻ trong nước có nhiều lo ngại trước nguy cơ thâm nhập của những "cá mập" quốc tế. Không chỉ giới kinh doanh, mà các nhà nghiên cứu và quản lý chính sách đều rất băn khoăn cho sự tồn tại của hệ thống bán lẻ trong nước trước không khí khẩn trương chiếm lĩnh thị trường của các trung tâm lớn như Big C, Metro hay Parkson và đang "lăm le" là những người khổng lồ như Carrefour và Walmart. Thế nhưng, cơn sóng lớn đầu tiên lại ập xuống các thị trường tín dụng, tiền tệ và chứng khoán.

Như chúng ta đã biết, từ cuối năm 2007, hệ thống tài chính thế giới sa vào khủng hoảng nghiêm trọng. Đây cũng là điểm bắt đầu của quá trình sụt giảm trên thị trường chứng khoán Việt Nam. Trong bối cảnh kinh tế trong nước cũng gặp nhiều khó khăn với giá cả tăng cao, tín dụng khan hiếm ở mức lãi suất cao, thanh khoản giảm trên nhiều thị trường, các nhà đầu tư Việt Nam bắt đầu ngắm chỉ số DJIA và Nikkei để đặt giá cho phiên giao dịch tiếp theo. Như vậy, có thể nói, quốc tế hóa đã vào tới túi tiền của từng nhà đầu tư Việt Nam.

Bảng 2: Tương quan chặt chẽ giữa các chỉ số chứng khoán

\begin{tabular}{|c|c|c|c|c|}
\hline Ngày & DJAI & Nikkei 225 & Vn-Index & Ghi chú(5) \\
\hline \multirow[t]{2}{*}{$30 / 9 / 2008$} & $-777,68$ & $-483,75$ & $-22,30$ & (1) \\
\hline & $-6,98 \%$ & $-4,12 \%$ & $-4,66 \%$ & \\
\hline \multirow[t]{2}{*}{$10 / 10 / 2008$} & -128 & $-881,06$ & $-18,58$ & (2) \\
\hline & $-1,49 \%$ & $-9,62 \%$ & $-4,68 \%$ & \\
\hline \multirow[t]{2}{*}{$16 / 10 / 2008$} & $-733,08$ & $-1089,02$ & $-12,54$ & (3) \\
\hline & $-7,87 \%$ & $-11,41 \%$ & $-3,16 \%$ & \\
\hline \multirow[t]{2}{*}{$23 / 10 / 2008$} & -514 & $-213,71$ & $-14,48$ & (4) \\
\hline & $-5,70 \%$ & $-2,46 \%$ & $-3,86 \%$ & \\
\hline \multirow[t]{2}{*}{$6 / 11 / 2008$} & $-443,48$ & $-622,1$ & $-13,54$ & (5) \\
\hline & $-4,85 \%$ & $-6,53 \%$ & $-3,57 \%$ & \\
\hline \multirow[t]{2}{*}{$11 / 11 / 2008$} & $-176,58$ & $-272,13$ & $-9,38$ & (6) \\
\hline & $-1,99 \%$ & $-3 \%$ & $-2,67 \%$ & \\
\hline
\end{tabular}




\section{II - Những thách thức đối với nền kinh tế nước ta trong năm 2009}

\section{1- Những thách thức đặt ra}

Kinh tế thế giới bước sang 2009 với nhiều lo âu và thấp thỏm. Mỹ, đầu tầu kinh tế toàn cầu sau khi "lên dốc" không thành vào quý III năm 2008, đã trượt dốc không phanh. Các kế hoạch cứu trợ khẩn cấp liên tiếp được đưa ra, với mức cứu trợ đã lên tới hơn 2.000 tỉ USD, nhưng chưa thể ngăn chặn được sự "bốc hơi” của lượng tài sản tài chính (bao gồm cả bất động sản đã tiền tệ hóa) lên tới hơn 30.000 tỉ USD.

Toàn thế giới đã chịu "chấn động" của "cơn sóng thần thế kỷ”. Lạm phát, giá hàng hóa, vật tư tăng cao. Giá dầu ngự trị trên "ngai" 149 USD/thùng, và đã từng được tiên đoán có thể vượt 200 USD/thùng. "Co rút" tín dụng và mất thanh khoản dòng vốn toàn cầu. Và rồi, giá dầu tụt xuống ngưỡng 40 USD, chẳng bao lâu sau "cái đỉnh" sắp chạm tới là 150 USD/thùng. DJIA xuống dưới 8.000 sau những phiên "co giật" kỷ lục, cả tăng và giảm, những mức dao động lớn mà chỉ có dịp thấy như thời kỳ sau vụ khủng bố ngày 11-9-2001. Người ta còn cho rằng, DJIA có thể xuống tới 6.500 , một con số đáng sợ. Trung Quốc, quốc gia láng giềng của nước ta, cũng dốc túi trong kế hoạch 600 tỉ USD cứu trợ...

Nếu tăng trưởng kinh tế năm 2008 của nước ta diễn ra theo đúng kịch bản 6,5\%, thì hy vọng rằng trong năm 2009 chúng ta vẫn tiếp tục là nền kinh tế thu hút nhiều sự quan tâm của cộng đồng kinh doanh và tài chính quốc tế. Tuy vậy, khó khăn về nguồn vốn và tín dụng quốc tế chưa đi qua. Thu hút vốn FDI trong năm tới sẽ gặp nhiều khó khăn. Quy mô vốn cam kết mới khó vượt qua con số kỷ lục của 2008. Ưu tiên đẩy nhanh tiến độ và tăng cường giải ngân các dự án đã có cam kết vốn trong những năm trước là lựa chọn hợp lý so với nỗ lực thu hút thêm các cam kết đầu tư mới. Ngân hàng Thế giới dự báo, dòng vốn tư nhân chảy sang các nước đang phát triển sẽ giảm mạnh từ 1.000 tỉ USD (năm 2007) xuống còn 530 tỉ USD trong năm 2009.

Bên cạnh đó, giá các tài sản tài chính tại Việt Nam đang ở mức rất thấp. Có thể coi đây là thời điểm thuận lợi cho khoản 10 tỉ USD - đang nằm tại các quỹ đầu tư, giải ngân vào Việt Nam. Lượng vốn FPI này gần tương đương với vốn FDI đã thực hiện trong năm 2008. Ưu thế của dòng vốn này là có khả năng nhân lên trong thời gian ngắn và tiếp tục vận động trong nền kinh tế Việt Nam cho tới hết thời gian hoạt động của quỹ, thường từ 7 đến 10 năm. Khả năng xuất hiện tình trạng rút vốn hàng loạt (capital flight) như từng xảy với nhiều quốc gia Đông á trong khủng hoảng 1997 hầu như không có với Việt Nam. Lý do căn bản là vì thị trường chứng khoán Việt Nam đã qua rất lâu thời kỳ đỉnh cao. Muốn khai thác hiệu quả dòng vốn FPI, cùng với hỗ trợ chính sách từ Chính phủ, tự thân các doanh nghiệp cần làm tốt công tác truyền thông tài chính, đẩy mạnh và phát triển thương hiệu.

Tỷ lệ thất nghiệp tăng cao sẽ trở thành vấn nạn của năm 2009, kéo theo hiệu ứng là các tệ nạn tiêu cực xã hội. Ước tính đến hết năm 2008, số người mất việc tại Mỹ lên tới nửa triệu, bao gồm cả nhóm lao động có kỹ năng và trình độ chuyên môn cao trong các lĩnh vực tài chính, ngân hàng và quản trị. Tại các quốc gia đang phát triển, áp lực việc làm tiếp tục gia tăng khi tăng trưởng kinh tế không theo kịp đà phát triển của lực lượng lao động. Việt Nam cũng không nằm ngoài nguy cơ này, hiện đã có những doanh nghiệp tại Hà Nội, Đồng Nai và một số tỉnh khác phải cắt giảm nhân 
lực để duy trì sản xuất.

Tạo đủ công ăn việc làm cho người lao động là một thách thức của nền kinh tế Việt Nam trong năm 2009. Khu vực doanh nghiệp, đặc biệt khối tư nhân, còn gặp nhiều khó khăn trong tiếp cận nguồn vốn tín dụng. Thu hẹp quy mô và giãn sản xuất, đồng nghĩa với việc cắt giảm nhân công hoặc sử dụng không hết thời gian làm việc, là những giải pháp phổ biến tại nhiều đơn vị sản xuất thời gian qua. Ngay trong khu vực vốn tạo nên cơn sốt nhân lực trong năm 2006 2007 là các ngành tài chính, ngân hàng và chứng khoán, cũng hình thành xu thế cắt giảm mạnh. Giá cổ phiếu xuống thấp cộng với quy mô giao dịch giảm mạnh đẩy không ít công ty chứng khoán lâm vào cảnh thua lỗ và hoạt động cầm chừng. Đơn cử như Chứng khoán Bảo Việt, công ty thuộc nhóm dẫn đầu của ngành có lịch sử hoạt động gắn bó với thị trường chứng khoán Việt Nam từ những ngày đầu tiên, sau 9 tháng đầu năm 2008 đã công bố khoản lỗ trên 300 tỉ đồng. Tại thời điểm công bố, ngày 22-10-2008, Vn-Index đang ở mức 374 điểm.

Mặt bằng lãi suất đã được điều chỉnh giảm dần suốt 6 tháng cuối năm 2008 nhưng trên thị trường tín dụng, ngân hàng và doanh nghiệp vẫn chưa tìm được tiếng nói chung. Quá trình tự điều chỉnh sẽ dẫn tới điểm chung. Vấn đề của hệ thống ngân hàng là sàng lọc tốt và lựa chọn các dự án thực sự có chất lượng, chỉ cần được tiếp đủ vốn là sẽ đạt tới quy mô sản xuất kinh doanh hiệu quả. Trong thời gian thị trường chứng khoán nước ta tăng trưởng đầy hào hứng kể từ giữa 2006 đến hết 2007, nhiều dự án đầu tư mở rộng hoặc phát triển mới đã được triển khai mà không có các đánh giá đầy đủ và cẩn trọng về mức độ khả thi thương mại, cũng như rủi ro thị trường. Đa phần các ngân hàng hiện nay đều có quy trình tín dụng với nhiều thủ tục nhằm bảo đảm mức độ an toàn cao cho các khoản vay. Tuy nhiên, phần cơ bản nhất là đánh giá tín nhiệm để phân cấp tín dụng, làm căn cứ xác định lãi suất và hạn mức cho từng khách hàng hay nhóm khách hàng vẫn chưa hoàn chỉnh.

Do tình trạng suy thoái kinh tế và thất nghiệp còn gia tăng, nhu cầu tiêu dùng trong năm 2009 sẽ giảm mạnh. Ngân hàng Thế giới ước tính mậu dịch thế giới sau khi tăng 6,2\% trong năm 2008 sẽ suy giảm còn 2,1\% trong năm tới. Từ đó, có thể xác định một năm khó khăn cho xuất khẩu Việt Nam đang ở phía trước. Mặc dù giá nhập khẩu cũng có xu thế giảm, nhưng muốn bảo đảm nhập siêu ở mức an toàn, cần tiếp tục kiểm soát chặt chẽ hoạt động nhập khẩu và cổ vũ thực hành tiết kiệm trong tiêu dùng và đầu tư.

\section{2 - Gợi mở chính sách và những vấn đề cần quan tâm}

Thực tế ứng phó với một năm khủng hoảng kinh tế của thế giới và Việt Nam khẳng định vai trò can thiệp và điều tiết kinh tế của các chính phủ là không thể thiếu. Mặt khác, sức mạnh của thị trường với các lực lượng tài phiệt công nghiệp, tài chính cũng không thể xem nhẹ. Khi giải quyết hậu quả của khủng hoảng, các chính phủ luôn bị ràng buộc bởi hạn chế ngân sách, bởi phần cơ bản nhất trong nguồn thu của chính phủ là thuế. Phần đáp ứng bội chi là các khoản vay nợ (phổ biến là thông qua phát hành trái phiếu) từ thị trường. Khả năng bù đắp, do vậy, phụ thuộc vào mức 
độ sẵn sàng của hệ thống tài chính tư nhân. Tính thời điểm và liều lượng can thiệp của nhà nước càng trở nên quan trọng hơn.

Diễn biến kinh tế, tài chính của năm 2008 thể hiện rõ ảnh hưởng có tính chất quyết định của van tín dụng tiền tệ thông qua công cụ lãi suất tới trạng thái hoạt động của nền kinh tế, cho dù đó là Mỹ, các quốc gia châu Âu, hay Việt Nam. Các thông tin điều chỉnh mức lãi suất luôn có tác động tức thì tới thị trường. Chỉ bằng một động tác siết van tín dụng, nền kinh tế có thể chuyển từ trạng thái tăng trưởng và mở rộng đầu tư sang cảnh ngưng trệ và đình đốn.

Tín dụng là đồng xu có hai mặt. ở một mặt, tín dụng là một phần của chu kỳ sản xuất. Việc mở rộng tín dụng sẽ khuyến khích đầu tư và cả chi tiêu của xã hội. Tổng cầu trong nền kinh tế tăng lên. Nền kinh tế có mức tăng trưởng tích cực và đời sống được cải thiện. ở mặt kia, nới lỏng tín dụng là khởi nguồn của sự hình thành bong bóng đầu cơ. Chính cựu Chủ tịch FED, Ây-lan Grin Spen đã thừa nhận, việc duy trì mức lãi suất thấp trong một thời gian dài là sai lầm và hậu quả tàn phá của sóng thần thế kỷ là vượt quá mọi sự tưởng tượng.

Trong thời kỳ biến động kinh tế, sự chỉ đạo quyết liệt từ cấp lãnh đạo cao nhất, phối hợp đồng bộ giữa các bộ, ngành chức năng và sự hỗ trợ tích cực của hệ thống truyền thông là những nhân tố then chốt để bình ổn thị trường. Truyền thông tốt phải bảo đảm một số yếu tố như: thông tin chất lượng; phương pháp truyền dẫn tốt; tiếp thu thông tin có định hướng hợp lý của xã hội và thị trường. Muốn vậy, công tác dự báo và nghiên cứu khoa học ứng dụng trong điều hành vĩ mô phải làm tốt. Ngay cả khi dự báo không hoàn toàn chính xác thì các mô hình điều khiển động học vĩ mô tốt cũng định hướng được lời giải hiệu quả vào những tình huống biến cố. Khẩn trương xây dựng và phát triển một học thuyết kinh tế của Việt Nam, cho Việt Nam, vì Việt Nam, giúp định hướng điều hành rõ nét, và chủ động hơn trong ứng phó trước những vận động bất thường của nền kinh tế thế giới và trong nước là việc cấp bách hiện nay./.

(1) Nhập siêu năm 2006 là 5.064,9 triệu USD, năm 2007 là 12.443 triệu USD

(2) CPI năm 2007 là 12,6\%, năm 1995 là 12,7\%

(3) Vương Quân Hoàng và Nguyễn Hồng Sơn: "Về mối quan hệ liên thông giữa các thị trường chứng khoán, bất động sản và tiền tệ", Tạp chí Cộng sản, số 785 (tháng 4-2008), tr 56

(4) Quyết định số 03/2008/QĐ-NHNN

(5) (1)- Ngân sách cứu trợ 700 tỉ USD của Hoa Kỳ không được thông qua; (2)- Chứng khoán phố Wall giảm 8 ngày liên tiếp; (3)- Thủ tướng Nhật Bản cho rằng cứu trợ 700 tỉ USD là chưa đủ; (4)- Kết quả kinh doanh kém của quý III năm 2008; (5)- Thất nghiệp ở Hoa Kỳ tăng mạnh; (6)- Nỗi lo suy thoái kinh tế lan rộng toàn cầu

\section{BÀI CÙNG CHỦ ĐỀ}

Năm 2009, 4 nghìn tỉ đồng hỗ trợ kiên cố hóa kênh mương, phát triển kết cấu hạ tầng nông thôn (21/01/2009)

Thêm 200 triệu USD vốn ưu đãi dành cho khu vực nông thôn (21/01/2009)

Triển khai gói giải pháp kích cầu: Giảm $50 \%$ thuế suất cho doanh nghiệp (21/01/2009) 
Bài học "Làm theo Bác" ở Cái Đôi Vàm (21/01/2009)

Giải quyết vấn đề nông nghiệp, nông dân, nông thôn ở Bình Phước (21/01/2009)

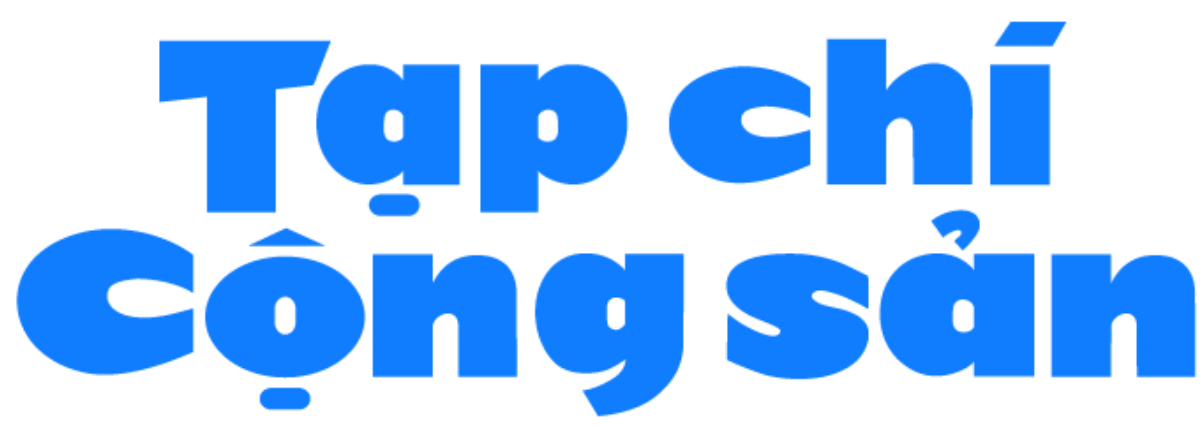




\section{TỔNG BIÊN TẬP: PGS,TS. ĐOÀN MINH HUẤN}

\section{Bộ Biên tập:}

Địa chỉ: Số 28, Trần Bình Trọng - thành phố Hà Nội

Điện thoại: 02439429753 - Fax: 02439429754

Email: tapchicongsandientu@tccs.org.vn

\section{Cơ quan Thường trực tại miền Trung - Tây Nguyên:}

Số 26 Trần Phú, thành phố Đà Nẵng

Điện thoại: (080) 51 301; Fax: (080) 51303

\section{Cơ quan Thường trực tại miền Nam:}

Địa chỉ: Số 19 Phạm Ngọc Thạch,

Thành phố Hồ Chí Minh

Điện thoại: (080) 84083; Fax: (080) 84081

\section{Văn phòng đại diện tại thành phố Cần Thơ:}

Địa chỉ: Số 86 Nguyễn Trãi, thành phố Cần Thơ

Điện thoại/Fax: (0710)6250868

\section{- HÀNH CHÍNH ĐIÊN TỬ \}

LIÊN HỆ GỬI BÀI VÀ ĐÓNG GÓP Ý KIẾN

LIÊN HÊ QUẢNG CÁO: 08046138

@Bản quyền thuộc về Tạp chí Cộng sản

Giấy phép số 436/GP-BTTTT ngày 14-10-2019 của Bộ Thông tin và Truyền thông.

Mọi hành động sử dụng nội dung đăng tải trên Tạp chí Cộng sản điện tử tại địa chỉ www.tapchicongsan.org.vn phải dẫn nguồn và có sự đồng ý bằng văn bản của Tạp chí Cộng sản 